УДК: 633.15.631.527

\title{
БИОХИМИЧЕСКИЕ ХАРАКТЕРИСТИКИ ЗЕРНА НОВЫХ УЛЬТРАРАННЕСПЕЛЫХ И РАННЕСПЕЛЫХ ГИБРИДОВ КУКУРУЗЫ
}

\author{
Перевязка Наталья Игоревна \\ Перевязка Дмитрий Сергеевич \\ младшие научные сотрудники
} Научный руководитель: Супрунов Анатолий Иванович д-р с.-х. наук Национальный центр зерна им. П.П. Лукьяненко

Аннотация: кукуруза - одна из самых востребованных зерновых культур в мире. Ежегодно увеличиваются площади возделывания данной культуры. Кукурузное зерно - важный пищевой и кормовой продукт, от качества которого зависит возможность дальнейшего применения данной культуры. В нашем исследовании проводился анализ основных биохимических показателей кукурузного зерна, таких как: содержание белка, жиров и углеводов, в новых ультрараннеспелых и раннеспелых гибридах кукурузы. По результатам работы были выделены новые гибриды кукурузы, отличающиеся высокими показателями содержания белка, жиров и углеводов относительно используемого стандарта.

Ключевые слова: гибриды, белки, жиры, углеводы, линии кукурузы, исходный материал.

\section{BIOCHEMICAL CHARACTERISTICS OF GRAINS OF NEW ULTRA-EARLY AND EARLY CORN HYBRIDS}

\author{
Perevyazka Natalia Igorevna \\ Perevyazka Dmitriy Sergeevich \\ Suprunov Anatoly Ivanovich
}

\begin{abstract}
The area of cultivation of this crop is increasing annually. Corn grain is an important food and feed product, the quality of which determines the possibility of further use of this crop. In our study, we analyzed the main biochemical parameters of corn grain, such
\end{abstract}


as: the content of protein, fats and carbohydrates, in new ultra-early and earlymaturing hybrids of corn. Based on the results of the work, new hybrids of corn were isolated, characterized by high levels of protein, fat and carbohydrates relative to the standard used.

Key words: hybrids, proteins, fats, carbohydrates, corn lines, starting material.

Введение. В настоящее время сельскохозяйственное производство шагнуло далеко вперёд благодаря развитию селекции культурных растений. Рост населения нашей планеты требует незамедлительной реакции селекционных организаций на возрастающие потребности в продуктах питания. Ежегодно создаются новые высокопродуктивные сорта и гибриды культурных растений, одна из основных сфер применения которых, сводится к использованию данных гибридов и сортов в качестве корма для сельскохозяйственных животных и получения продуктов питания, и различного рода питательных веществ, для нужд человека.

Одним из основных продуктов, производимых культурными растениями, является их зерно, в состав которого входит множество необходимых питательных элементов, таких как: белки, жиры и углеводы. От количественного содержания данных элементов, зависит качество используемого зерна. Кукуруза - одна из основных культур, использующихся в производстве продуктов питания как для человека, так и для животных. Кукурузное зерно - кладовая полезных веществ, использующаяся для производства муки, масла, крахмала, спиртов и т.д. Поэтому в селекционных организациях уделяется значительное внимание количественному содержанию основных элементов, таких как: белки, жиры и углеводы $[1,2]$.

Материал и методы. Работа по созданию и изучению новых гибридов проводилась в течение трёх лет на опытных полях НЦЗ им. П.П. Лукьяненко (2018 - 2020 годы). Изучение биохимических показателей кукурузного зерна проводилась в 2020 году проведения исследований. Для создания новых ультрараннеспелых линий было привлечено 6 кремнистых и 2 зубовидные линии. Кремнистые линии: 721 $\mathrm{MBSF}_{4-1-1}, \mathrm{Kp} \mathrm{681,} \mathrm{СМ7МВ,} \mathrm{Ол} \mathrm{2,} \mathrm{328,}$ Кр 721 MB. Зубовидные линии: PLS61, 801 MB. Для новых гибридов были использованы три ультрараннеспелых тестера - гибрида: Кр 703М х BS16 $22-1-1$, Кр 703М х BS10 (г.) и Кр 703М х Ол145. Во всех трех зубовидных тестерах присутствовала раннеспелая линия Кр 703 и три ультрараннеспелые линии выделенных из популяции позднего цикла отбора на раннее цветение - BS3 и 
BS10. Для создания новых раннеспелых линий кукурузы было привлечено 6 зубовидных и 6 кремнистых линий кукурузы. Зубовидные линии: Кр 802 МВ,

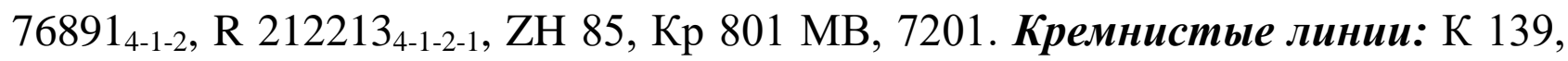
Гк 81, Кр 721 МВ, Ол 2, СМ7MB, 782. Для создания новых гибридов были использованы три тестера - гибрида гетерозисной группы iodent x SSS: Кр 752 M x 740, Кр 714 M x 752, Кр 742 М x Кр 714 К2 $2_{14-2-2-1 .}$

Результаты. Исследования, направленные на изучение биохимических показателей зерна, проводились в два этапа. Сначала изучались показатели зерна в блоке ультрараннеспелых гибридов кукурузы, затем показатели зерна изучались в блоке раннеспелых гибридов кукурузы. К блоку ультрараннеспелых гибридов кукурузы, в качестве стандарта, был подобран районированный гибрид Росс 130 МВ. К блоку раннеспелых районированный гибрид Краснодарский 194 МВ. Каждый стандарт соответствовал группе спелости изучаемых гибридов.

Изучение биохимических показателей кукурузного зерна производилось на аппарате Infratec 1241. Данный аппарат работает по принципу фотоэлектроколориметра в спектральном диапазоне длины волны 570-1100 нм.

Результаты изучения биохимимческих показателей зерна ультрараннеспелых гибридов кукурузы представлены в таблице 1.

Таблица 1

Биохимические характеристики лучших новых ультрараннеспелых гибридов кукурузы, Краснодар, 2020 год

\begin{tabular}{|c|c|c|c|}
\hline Название гибрида & Жиры, \% & Белок, \% & Крахмал, \% \\
\hline POCC $130(\mathrm{st})$ & 3,8 & 12,6 & 70,1 \\
\hline Две 1121 MB x (703 M x OL 145) & 4,1 & 13,8 & 68,9 \\
\hline $\mathrm{BS3}_{3-1-2-3-1-2} \times(703 \mathrm{M}$ x OL 145) & 4,3 & 13,3 & 69,2 \\
\hline Ол 28613284-2-1 х (703 M х OL 145) & 4,9 & 14,0 & 68,1 \\
\hline CM7MB81 16-1-1 x (703 M x OL 145) & 4,8 & 12,5 & 69,1 \\
\hline $\mathrm{CM} \mathrm{MB} 81_{17-1-1} \times(703 \mathrm{M}$ x OL 145) & 4,1 & 13,2 & 69,6 \\
\hline ОЛ $2801_{25-1-1}$ x (703 M x OL 145) & 4,2 & 13,1 & 69,7 \\
\hline Две $1121 \mathrm{MB}$ х $\left(703 \mathrm{M} * \mathrm{BS} 16_{22-1-1}\right)$ & 3,7 & 13,9 & 69,4 \\
\hline Ол 28613284-2-1 х (703M * BS1622-1-1) & 4,5 & 13,1 & 69,1 \\
\hline УК 81 х (703 M x BS 10 (г.)) & 4,2 & 12,6 & 69,2 \\
\hline $\mathrm{CM}^{2} 81_{26-1-1}$ x (703 M x BS 10 (г.)) & 4,2 & 13,6 & 69,2 \\
\hline
\end{tabular}


Исходя из данных, представленных в таблице 1 можно сделать следующие выводы: процентное содержание жиров в зерна лучших ультрараннеспелых гибридов кукурузы составляло от $3,7 \%$ до 4,9\%. Содержание белка составляло от $12,5 \%$ до 14,0\%. Содержание крахмала составляло от 68,1\% до 69,7\%. Особенно хочется выделить гибрид кукурузы Ол 28613284-2-1 х (703 M х OL 145). Данный гибрид превысил использующийся стандарт Росс 130 MB по содержанию белка и жиров (4,9\% жиров и 14,0\% белка).

Далее аналогичные исследования проводились в блоке раннеспелых гибридов кукурузы. Результаты работы представлены в таблице 2.

Таблица 2

Биохимические характеристики лучших новых раннеспелых гибридов кукурузы, Краснодар, 2020 год

\begin{tabular}{|c|c|c|c|}
\hline Название гибрида & Жиры, \% & Белок, \% & Крахмал, \% \\
\hline Краснодарский 194 МВ & 4,5 & 10,4 & 70,9 \\
\hline $802244_{4-1-2-1-1-2} \times(714 \mathrm{M} \times 752)$ & 4,8 & 12,9 & 68,9 \\
\hline $1498_{2-1} \times(714 \mathrm{M} \times 752)$ & 4,3 & 13,1 & 69,1 \\
\hline Ол $2801_{10-1-1-1} \times\left(742 \mathrm{M} * 714 \mathrm{~K} 2_{14-2-2-1}\right)$ & 5,3 & 11,1 & 70,0 \\
\hline Ол $2801_{21-1-1}$ х $\left(742 \mathrm{M} * 714 \mathrm{~K} 2_{14-2-2-1}\right)$ & 5,3 & 12,8 & 68,3 \\
\hline Ол $2801_{25-1-1-2} \times\left(742 \mathrm{M} * 714 \mathrm{~K} 2_{14-2-2-1}\right)$ & 4,9 & 11,4 & 69,7 \\
\hline $721 \mathrm{MB} \times\left(742 \mathrm{M} * 714 \mathrm{~K} 2_{14-2-2-1}\right)$ & 4,9 & 11,9 & 69,1 \\
\hline $85721_{16-1-1} \times\left(742 \mathrm{M}^{*} 714 \mathrm{~K} 2_{14-2-2-1}\right)$ & 4,8 & 11,8 & 69,7 \\
\hline \multicolumn{4}{|c|}{ Продолжение таблицы 2} \\
\hline Гк $81 \mathrm{MB} \times\left(742 \mathrm{M}^{*} 714 \mathrm{~K} 2_{14-2-2-1}\right)$ & 4,9 & 12,1 & 69,2 \\
\hline См 7819-1-1-1 х $\left(742 \mathrm{M}^{*} 714 \mathrm{~K} 2_{14-2-2-1}\right)$ & 4,8 & 11,4 & 69,9 \\
\hline $1489_{14-2} \times\left(742 \mathrm{M}^{*} 714 \mathrm{~K} 2_{14-2-2-1}\right)$ & 4,8 & 11,4 & 69,4 \\
\hline $1489_{16-1} \times\left(742 \mathrm{M} * 714 \mathrm{~K} 2_{14-2-2-1}\right)$ & 4,5 & 11,2 & 69,8 \\
\hline $1498_{2-1} \times\left(742 \mathrm{M}^{*} 714 \mathrm{~K} 2_{14-2-2-1}\right)$ & 4,9 & 12,1 & 69,1 \\
\hline $1499_{4-1} \times\left(742 \mathrm{M} * 714 \mathrm{~K} 2_{14-2-2-1}\right)$ & 4,9 & 12,1 & 68,9 \\
\hline $802244_{3-2-1-1-1} \times\left(752 \times 714 \mathrm{~K} 2_{14-2-2-1} \mathrm{M}^{5}\right)$ & 4,5 & 11,9 & 70,5 \\
\hline $802244_{4-1-2-1-1-2} \times\left(752 \times 714 \mathrm{~K} 2_{14-2-2-1} \mathrm{M}^{5}\right)$ & 5,0 & 12,2 & 69,0 \\
\hline Гк 81 MB х $\left(752\right.$ х 714K214-2-2-1 $\left.\mathrm{M}^{5}\right)$ & 5,1 & 11,2 & 69,3 \\
\hline
\end{tabular}

По результатам, представленным в таблице 2 можно сделать следующие выводы: содержание жиров в зерне новых раннеспелых гибридов кукурузы составляло от 4,3\% до 5,3\%. Содержание белка в зерне составляло от $11,1 \%$ до $13,1 \%$. Содержание крахмала составляло от $69,0 \%$ до 70,5\%. Особенно хочется выделить раннеспелый гибрид кукурузы Ол $2801_{21-1-1}$ х $\left(742 \mathrm{M}^{*} 714 \mathrm{~K} 2_{14-2-2-1}\right)$, превышающий используемый стандарт Краснодарский 194 МВ по содержанию жиров и белка $(5,3 \%$ и $12,8 \%)$. 
Заключение. Таким образом, нами было проведено изучение содержания основных биохимических показателей кукурузного зерна - жиров, белков и крахмала в двух блоках новых гибридов кукурузы, что позволит нам сформировать селекционные программы, исходя из полученных результатов.

\section{Список литературы}

1. Волкова Н.А. Технологические и биохимические показатели качества зерна озимых культур в Северном Зауралье: Автореф. дисс....канд. с.-х. наук / Н.А. Волкова - Тюмень, - 2015 - 19 с.

2. Губанова В.М. Технологические и биохимические характеристики зерна плёнчатого и голозёрного ячменя в условиях Северного Зауралья [электронный ресурс] / В.М. Губанова, М.В. Губанов // Пермский аграрный вестник. - 2018. Т. 24. № 4. Режим доступа:https://cyberleninka.ru/article/n/ tehnologicheskie-i-biohimicheskie-harakteristiki-zerna-plyonchatogo-igolozyornogo-yachmenya-v-usloviyah-severnogo-zauralya.

() Н.И. Перевязка, Д.С. Перевязка, А.И. Супрунов, 2021 